\title{
Treasury Single Account Compliance: Accounting Practices for Effectiveness and Sustainability in Institutions
}

\author{
Raji Gbolagade Mojeed*1 \& Adekola Adeola Adebayo², Opadotun Tunde Adewumi ${ }^{3}$ \\ ${ }^{*}{ }_{1,2}$ Department of Accountancy, The Polytechnic, Ibadan, Nigeria \\ ${ }^{3}$ Department of Accountancy, Adeseun Ogundoyin Polytechnic, Eruwa, Nigeria \\ *Corresponding author
}

\begin{abstract}
This study considered treasury single account compliance as an accounting practice for effective and sustainability in institutions. The general objective is on how treasury single account could plug leakages within the system, while the specific objective would be on how treasury single account could dovetail into a transparent reportage in a system. Legitimacy theory and public finance management theory adopted for the treasury single account, therefore foresees that government will implement policies to guarantee the society and that agencies are complying by disclosing all transactions in treasury single account. This study was based on the data from both primary source and empirical works of previous researchers. The questionnaires were administered to the bursary staff of The Polytechnic in Ibadan. The questions were on the five-point Likert type questions, with a choice of strongly agree to strongly disagree. The data gathered were analyzed using chi-square statistical packages for social sciences. Data were gathered from the questionnaires analyzed using chi-square in SPSS, and findings revealed that treasury single account compliance have a significant effect in the effective accounting practices and sustainability in institution. This paper concluded that loss of revenue has a multitude of collision on effects, including the fact that lower revenue means that less money will be available to provide facilities for sustainability. Therefore, this paper recommends that, the effectiveness of treasury single account compliance (TSAC) should be broadminded for the sustainability in institutions. There should be seal for both transparency and accountability to block the leakages within the system. The permissible laws should be appraised and adapted where mandatory training should be offered to appropriate bursary staff of The Polytechnic Ibadan to guarantee effective operation.
\end{abstract}

Keywords: Accountability, Governance, Institutions, Sustainability, Transparency, Treasury single account compliance

\section{INTRODUCTION}

$\mathrm{T}$ reasury single account is a critical social consequences that serve as a motivating factor in government public sector accounting designed solely to minimize financial crime such as bribery and corruption, money laundering, fraud, theft and to ensure proper monitoring of government receipt, revenue in an enabling environment. According to Kifasi (2016), this is a combined government bank account or a conventional of connected accounts complete which all government receipts and payments are transacted. Kifasi (2016) stated further, that it enables the office of AccountantGeneral of the state to know at any time the consolidated cash position of state government. Public institutions are apprehension for sustainability for growth and development and further said, public institutions are deep-rooted with corruption, lack of accountability and transparency. Nonexistence of good governance have been widespread and become the order of the day (Akharayi, 2015). This has led to weak controls and encourage corruption and is made probable when controls are non-existed or without prosecution by the people in management.

The Federal Republic of Nigeria Constitution (2010) stated that the Central Bank of Nigeria is accountable for the upkeep and supervision on such account. In a nutshell, treasury single account, according to section 80(1) of the 1999 constitution as amended posited that:

"all revenue or other money raised or received by the
Federation not being revenue or other money payable
under this Constitution or any Act of the National
Assembly into any other public fund of the Federation
established for a specific purpose shall be paid into
and form one Consolidated Revenue Fund of the
Federation".

This was advocated by International Monetary Fund (IMF) (2010), as part of significant module of the economic transformation of government to stipulate a broad representation on the social and financial influence of financial crime. Loss of revenue to governments has a multitude of collision on effects on providing indispensable services. Oguntodu, Adekunle, Alalade and Adegbie (2016) elucidate TSA as unified structure of government bank account that stipulates a thoughtful of cash resources. Nonetheless Adeolu (2015) perceives treasury single account as a public accounting system, whereas Nelson, Adeoye and Ogah (2015) charge treasury single account as an account that all ministries and government departments' account balances are collected by the Central Bank, however there is an intermediate account for every ministry and department that displays the total of all debt and credit transactions. 
Due to challenges and enormous in the bridging the gaps of corruption with the misapplication and mismanagement of government funds and to improve the economic situation in the country the think tank has to come up with the idea to advise government for the adoption of treasury single account in order to provide a clear picture as possible on the social and effect of financial crime. Therefore, there is an intensifying interest by researcher to look inward how treasury single account could be accounting practices for effective and Sustainable Institutions as a policy paper for the government. To achieve this objective, the remaining parts of this paper are structured as follows: the second part reviews the literature; conceptual, theoretical, and empirical on treasury single account while the third part is on methodology adopted while the fourth indicates the conclusion in the study. Finally, the study recommendations serve as a major contribution to research.

\subsection{Statement of the problem}

The lapses of the state government to domesticate the detailed information in the aspects of treasury single account made implementation of treasury single account more cumbersome. Apart from remita which is locally based, there should be other systems to support TSA which manages commercial bank account as well interbank settlement which manages government accounts and for budgeting, transaction initiation and financial reporting. As a result of non-publication of audited annual reports tends to put avoidable blight on the achievement and challenges causing the delay.

\subsection{Objective of the study}

The general objective of the study is to evaluate how treasury single account (TSA) could plug leakages within the system. The specific objective would be on how TSA could dovetail into a transparent reportage in a system.

\subsection{Research Questions}

i. Can the treasury single account block the leakages within the system?

ii. Can treasury single account dovetail into transparent reportage in a system?

\section{LITERATURE AND THEORETICAL REVIEW}

\subsection{Conceptual Review}

\subsubsection{Corruption}

Corruption is an act which swerves from the prescribed rubrics of behavior overriding the activities of an individual holding position of public power standing (Heywood, 2017; Burdhan,2006). Corruption is the caricature of veracity over bribery and moral decadence (World Bank, 2011). In the nutshell, corruption is a methodical immorality in an individual, which replicates, undue enrichment, abuse of office, window dressing, aiding, and abetting of any kind to the disadvantage of another person in the society (Kolstad \& Wiig, 2009; Oiken, 2009; \&Transparency International, 2012
\& 2013; Independence Corrupt Practices and other related Offences Act (2000). Marqutte and Peiffer (2014), in recent years, posited that collective consideration has been enthusiastic to empathetic the motives for and significances of corruption.

Scholars of international repute have shown that the focal aspect affecting the possibility of corruption stand on the eminence of the officialdom, the inequalities of public sector wealth (Rickegham and Weder, 2007). Studies in this respect have analyzed the effect of corruption on output development and quality of public infrastructure (Shifer and Vishney, 2003), In such a system, corrupt behaviour infringes official procedures, laws, and general expectations for proper behaviour of its public officials.

Numerous features have been acknowledged as contributory to crowning corrupt practices, especially in Nigeria. The clear signal authenticate that they have the following connection: political and social diversity. Consequently, the socio-political economy system could make the citizens more disposed to corrupt activities. Nevertheless, Blackburn \& Sarmah (2008) stress that the vital influences that have stimulate and continual corrupt practices in Nigeria include:

i. The weak institutions of government, ii. Dysfunctional legal system.

\subsubsection{Accountability and Transparency and Treasury single account}

Transparency and accountability as identical perception is entrenched in the straightforward moral underpinning for creditable and monitoring accounting practice. Consequently, accountability is the core and passion of good governance and transparency is the reinforcing stimulus, this would enhance the treasury single account for the effective accounting practice (Akpa, 1997; Blackburn \& Forgues-Puccio, 2009).

Accountability is a precept requiring that the government's action be reported, explained, and justified to the people from time to time on consistent basis. Transparency can be described as the state of being exposed to the society at all level of governance (Blackburn et.al., 2009). This denotes to a state of comprehensive and unrestricted current of information. In a society occupied by transparent individuals, want supercede voracity, while directness is a maxim for all government transactions (Blackburn et al., 2009).

From the fiscal perspective, transparency necessitates that; issue of periodic statements of policy objectives and measurable targets, vibrant public accounts and predictions trusting on accrual based recording merely augmented by cash flow data, and uphold publicly some consistency amid the budget and government statement of financial position (Kopits and Craig, 1998).

Prudency and effective management are the key to ensuring that the citizenry living in safe and secure environment. Financial governance has its roots in the quality of the 
institutions that regulate tax, public financial management systems, and audit processes. All these serve as the suitable basis that must be put in place for the funds of the country be useful shrewdly (Blackburn et.al., 2009).

The consequences and existence of a single treasury account improves the supervision of cash flow can be enumerated as follows:

i. The existence of a recognized chain of command condense for outflows,

ii. It recovers electronic infiltration in public finances,

iii. The creation of treasury single account diminishes instability in cash over the treasury, consequently consenting for comparatively lower cash reserve safeguard.

iv. Reconciliation in government statement of financial position is easier due to the zero-based account approach (Central Bank of Nigeria, 2015).

\subsubsection{Sustainability in Institutions and Treasury single Account}

The idea of sustainability in institution is a multifaceted matter but grounded on three vital characteristics of sustainability: economic, social, and environmental. According to World Commission on Environment and Development, (1987); Harris, (2000) sustainability in institutions can be understood as an institution that encounters the desires for the facility for imminent generations to meet their own needs.

Sustainability in institution is an objective each country desires to accomplish. It encompasses economic growth that does not negotiate the imminent of productions. Yusuff (2016) posited that, sustainable institution is not a monophonic skillful focus, nonetheless concerns to all occupations as sustainable institution is an advance that is all-embracing. The sustainability of some endeavour can only be appraised when it pledges reality and steadiness of that career and people at large in successive years.

\subsection{Theoretical Framework}

\subsubsection{Public Finance Management Theory}

The theory emphasized that all features of government funds for are the benefits of the citizenry. It includes resources mobilization, arrangement of programmes, the budgetary process, efficient management of resources and exercising control to guide against corruption. Treasury Single Account largely is to circumvent mishandling of public funds. Ekubiat and Ime (2016) posited that government funds at all levels have not been adequately accounted for by preceding administration. The study looks inward on how treasury single account could serve as an effective accounting practices for sustainable institutions as policy for the government.

Grubber (2005) provides that mobilization and expenditure of financial resources need to be well managed by the government for the main benefit of the citizens. The people elect the government to work for them, therefore, government must be responsive to their needs in all aspect. And for this to be achieved, government must be in total control of the nation resources, mobilize it appropriately, prioritize its programme, budget process and manage efficiently cash resources which is the key function of TSA. This will go a long way to help government in good governance, efficient resources management, transparency.

\subsubsection{Legitimacy Theory}

Legitimacy theory is resultant from the idea of administrative legitimacy as distinct by Dowling and Pfeffer (1975) as a form which happen when an entity's value system is consistent with the value system of the greater social system of which the entity is part. Legitimacy theory, then, considers that government would want to function within the confines and standards of their corresponding societies. Kirtley (2016) supported that governments descend their legitimacy from the sovereignty of the citizens and duty of obligation make strategy pronouncements that would augment the eminence of life of the people. This will endeavor to meet the prospects of society in rapports of information disclosure, accountability, and value significance of information delivered to users.

Conceptual Framework

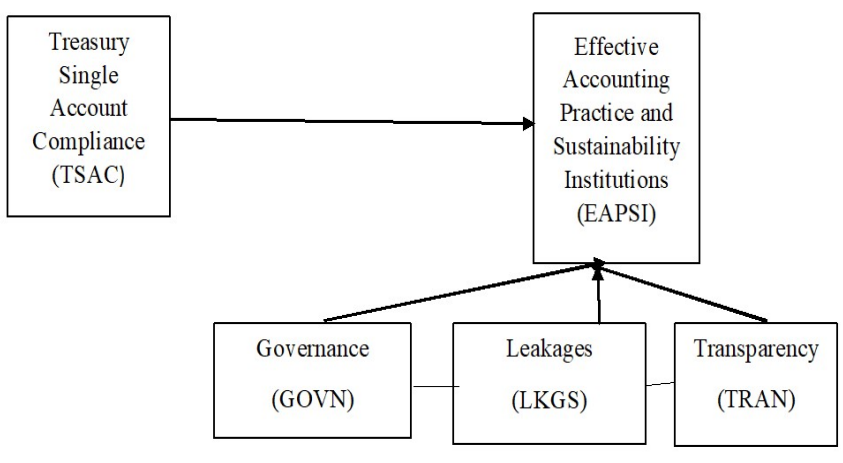

Source: Researcher's Conceptual Framework (2021)

\subsection{Empirical Review}

According to Isa (2016), treasury single account as an instrument of financial prudence and management. In addition, it is focuses on honesty, and resolve to astonish the innumerable encounters known. Moreover, Bashir (2016) scrutinizes the consequence of Treasury Single Account policy on public financial management in Nigeria. The author observes the degree TSA has impassable financial outflows, endorse transparency and accountability in public financial management.

Abayelu, (2015) and Daily Trust Editorial, (2015) posit that, the awareness of treasury single account came into being when some agencies rebuffed to declare their annual revenue they made to the treasury as necessitated by law. In 2012 about N120 billion was vehemently collected by government from MDAs being 25 percent of their gross revenue to the treasury with another N34 billion collected. 
Adeolu, (2016), Onyekpere (2015), and Jegede (2015). reiterated that the purpose is primarily to ensure accountability of government revenue, enhance transparency and avoid misapplication of public funds. The maintenance of a Treasury Single Account will help to ensure proper cash management by eliminating idle funds usually left with different commercial banks and in a way to enhance reconciliation of revenue e collection and payment.

Oyedele (2016), held TSA will expand the synchronization of fiscal and monetary policy, as it will project enhanced transparency via the understanding of fiscal and banking information, thus fundamental to an enhanced value of fiscal evidence and management that will help and recover the country's economy largely. TSA is considered to eradicate administrative confidentiality around public fund in MDAs.

The awareness of accounting officers and politicians team up to bring out all means of business with government funds previously effecting projects, triggering superfluous postponements or converting interest rates for private gains with banks will be disregarded. Moreover, revenue-generating MDAs will no retentive be clever to deny treasury of outstanding revenue through an overabundance of bank accounts which remain unidentified to the authorities. (Oyedele, 2015).

Yusuff (2016) posit that, sustainability development is a goal every nation aspires to attain. It involves both economic developments and economic growth that does not compromise the future of generations. Sustainability development is not a mono professional subject but applies to all professions as sustainable development is a development that is all encompassing. The sustainability of any endeavour can only be evaluated when it guarantees existence and continuity of that profession and humanity at large in subsequent years.

Kirtley (2016) IFAC President in her paper presented titled 'Accountability and Good Governance keen to the circumstance that governments descend their legitimacy from the sovereignty of the citizens and duty of obligation make strategy pronouncements that would augment the eminence of life of the people. She stresses further, good governance is about the openness of the government to the contemporary and imminent needs of the country, substitute with judiciousness and attention in the unsurpassed curiosity of stakeholders. Furthermore, good governance necessitates stand-in dependably in the public awareness, well-organized and active use of public funds to encourage the mutual good in transparent and accountable.

Cohen (2016) postulated that a public misunderstanding among Nigerians was that only designated officers remain to be apprehended answerable for the areas of good governance to be accomplished. He further stresses that people have a duty to screen the routine of individuals in power to guarantee that they continuously perform in the public curiosity and to promote apprehension where there is derailment. Entire sectors of the humanity such as the press, religious bodies, civil societies, the common man as well the elites necessitate to be vigilant towards their concern and call individuals in power to order as the necessity occurs. The working together from this joint concern would stretch means in scrutiny corruption and inaugurate good governance practices.

Oyedele (2016) and Oyedokun (2016), acknowledged that, it resolve convey about enhanced budget presentation, lesser cost of public projects, rapid payment of project, transparency in remaining funds assigned in the budget which might be booked forward to the succeeding period and condense total borrowing costs which is currently 1 trillion, about one third of the federal government revenue before borrowing. Kifasi (2016) elucidates some of the initiative which are already yielding results are stated below:

i. Government Integrated Financial Management (GIFMIS) is an IT based system for budget management and account to improve public expenditure management. It enhances greater accountability and transparency.

ii. E-payment system, this involve automated processing of transactions through information without physical evidencing. Funds are transferred electronically, and value given immediately.

\section{METHODOLOGY}

The nature of research design available for this study is the survey research design. The choice of the study enclosed with state owned institution, The Polytechnic Ibadan, in Oyo state. The endorsement for this choice is because of the usefulness connected with in gathering the proper information treasured for the study. The judgmental sampling method and simple random method were used in the study. The judgmental sampling technique was used because of the researcher's belief on the sample that will demand the predicted conclusion. That is, the study was grounded on the stateowned institution, The Polytechnic Ibadan, in Oyo state which the researchers believe will provide the appropriate people who will give the proper information. On the other hand, the simple random technique was used because every participant has uniform chance of being picked. Primary data was extracted using structured questionnaire as the research instrument Likert scale ranking of strongly agree (5); Agree (4); undecided (3); Disagree (2); strongly disagree (1). Finally, the hypotheses were tested using Chi-Square test statistics

$\mathrm{X}^{2}=\sum \frac{(\mathrm{O}-\mathrm{E})^{2}}{\mathrm{E}}$

Where: $\mathrm{O}=$ observed Frequency

$\mathrm{E}=$ Expected Frequency

$\mathrm{DF}=$ Degree of Freedom $=5-1=4$

While the data was analyzed through student's Package for Social Sciences (SPSS). 


\section{DECISION RULE:}

If the test statistic exceeds the critical value from the chisquare statistical table with the chosen significance 0.05 level reject Null hypothesis. Grounded on the complications acknowledged as well as the question, the hypotheses that guide this research work are:

$H_{1}$ : There is no significant relationship between treasury single account compliance and plug leakages within the system.

$\mathrm{H}_{2}$ : There is no significant relationship between treasury single account compliance and dovetail into a transparent reportage within the system.

\section{PRESENTATION OF DATA, ANALYSIS OF RESULTS AND INTERPRETATION}

\subsection{Descriptive Analysis}

Bursary departmental staff of The Polytechnic Ibadan previously stated were sampled and copies of the questionnaire were administered to them to gather information relevant to the study. A total of one hundred and fifty (150) copies of questionnaire administered and useable responses were obtained. This epitomizes a response rate of respondents as obtainable in table.

Table 1: Analysis of response rate

\begin{tabular}{|c|c|c|}
\hline Description & Number & Percent \\
\hline $\begin{array}{c}\text { Copies of questionnaire } \\
\text { distributed }\end{array}$ & 150 & 100 \\
\hline $\begin{array}{c}\text { Copies of questionnaire } \\
\text { returned }\end{array}$ & 135 & 90 \\
\hline $\begin{array}{c}\text { Copies of questionnaire } \\
\text { not returned }\end{array}$ & 15 & 10 \\
\hline
\end{tabular}

Source: Field survey, 2021

The above table show that 150 copies of questionnaire were distributed out of which 135 copies were duly completed and returned. This shows that the questionnaires were overwhelming completed as only 15 respondents failed to return their completed questionnaires. This represent $10 \%$ response failure rate but $90 \%$ response success rate.

Table 2: Demographic characteristics

\begin{tabular}{|c|c|c|}
\hline Variables & Frequency & Percent \\
\hline Gender: & 88 & 65.2 \\
Male & 47 & 34.8 \\
Female & 135 & 100 \\
Total & & \\
\hline Age: & 71 & $\sim 53.00$ \\
$30-35$ & 40 & $\sim 30.00$ \\
$40-45$ & 18 & $\sim 13.00$ \\
$50-55$ & 6 & $\sim 04.00$ \\
$60+$ & 135 & 100 \\
Total & 3 & 02.22 \\
Level of Education: & 22 & 16.30 \\
FCA/ACA & 92 & 68.15 \\
Masters & 18 & 13.33 \\
BSc/HND & & \\
ND & & \\
\end{tabular}

\begin{tabular}{|c|c|c|}
\hline Total & 135 & 100 \\
\hline Marital Status: & 66 & 48.9 \\
Single & 69 & 51.1 \\
Married & 135 & 100 \\
Total & 54 & \\
\hline Length of Service: & 42 & 40.00 \\
$1-5$ & 29 & 31.11 \\
$6-10$ & 10 & 21.48 \\
$11-15$ & 0 & 07.41 \\
$16-20$ & 0 & 00.00 \\
$21-25$ & 135 & 00.00 \\
$26-30$ & & 100 \\
Total & & \\
\hline
\end{tabular}

Source: Field Survey, 2021

\section{Table 2:}

Portrayed above reveals that 111 of the respondents (83\%) were aged between 30 to 45 years. Furthermore, 24 (17\%) respondents were in the age bracket of 50 to 60 years. Also, in the table reveals further that most of the respondents 114(84.45\%) possessed Master and First Degree respectively, while 18 respondents possessed National Diploma and finally, only 3 respondents claimed to be professionals. The analysis shows that the professionals that were expected with high intellect based on their professional training which should lend credence to the findings were low. In addition, about $69(51.1 \%)$ were married, 66(48.9\%) lived single. Finally, the gender, 88 respondents $(65.2 \%)$ were Male, and 47 respondents (34.8\%) were Female.

Table 3: Analysis of response

\begin{tabular}{|c|c|c|c|c|c|c|}
\hline $\mathrm{S} / \mathrm{N}$ & Descriptions & $\begin{array}{c}\text { SA } \\
5\end{array}$ & A 4 & $\begin{array}{c}\text { UD } \\
3\end{array}$ & D 2 & $\begin{array}{c}\text { SD } \\
1\end{array}$ \\
\hline 1 & $\begin{array}{l}\text { TSAC is acceptable by } \\
\text { The Polytechnic Ibadan }\end{array}$ & 35 & 54 & 19 & 17 & 09 \\
\hline 2 & $\begin{array}{c}\text { There is effective and } \\
\text { smooth running TSAC } \\
\text { by The Polytechnic } \\
\text { Ibadan }\end{array}$ & 17 & 49 & 29 & 20 & 20 \\
\hline 3 & $\begin{array}{c}\text { TSAC policy } \\
\text { significantly assist in } \\
\text { blocking revenue } \\
\text { linkages }\end{array}$ & 26 & 60 & 35 & 09 & 05 \\
\hline 4 & $\begin{array}{l}\text { TSAC helps in curbing } \\
\text { mismanagement and } \\
\text { misappropriation of } \\
\text { revenue }\end{array}$ & 20 & 50 & 43 & 22 & 00 \\
\hline 5 & $\begin{array}{c}\text { TSAC has reduced } \\
\text { corruption }\end{array}$ & 31 & 62 & 22 & 18 & 02 \\
\hline 6 & $\begin{array}{l}\text { TSAC promotes } \\
\text { transparency and } \\
\text { accountability }\end{array}$ & 25 & 63 & 32 & 11 & 04 \\
\hline 7 & $\begin{array}{c}\text { Changing government } \\
\text { policies influence } \\
\text { TSAC } \\
\end{array}$ & 49 & 47 & 30 & 07 & 02 \\
\hline 8 & $\begin{array}{c}\text { Bureaucracy affects } \\
\text { TSAC }\end{array}$ & 26 & 49 & 42 & 15 & 03 \\
\hline 9 & $\begin{array}{c}\text { TSAC enhances } \\
\text { effective accounting } \\
\text { practices }\end{array}$ & 17 & 64 & 42 & 12 & 00 \\
\hline 10 & $\begin{array}{l}\text { Implications of TSAC } \\
\text { affects sustainability in } \\
\text { Institutions }\end{array}$ & 21 & 55 & 37 & 19 & 03 \\
\hline 11 & TSAC affect the & 35 & 41 & 35 & 22 & 02 \\
\hline
\end{tabular}




\begin{tabular}{|c|c|c|c|c|c|c|}
\hline & $\begin{array}{c}\text { liquidity on money } \\
\text { deposited in Banks }\end{array}$ & & & & & \\
\hline 12 & $\begin{array}{c}\text { TSAC helps to conserve } \\
\text { funds for development }\end{array}$ & 22 & 56 & 43 & 10 & 04 \\
\hline
\end{tabular}

Strongly Agree 5 (SA), Agree 4 (A), Undecided 3 (UD), Disagree 2 (D), Strongly Disagree 1 (SD)

Source: Field Survey, 2021

\section{Interpretation}

The responses from the first question shows that 36(26.67\%) of the respondents strongly agree,54 (40\%) respondents Agree, $19(14.07 \%)$ of the respondents were undecided, $17(12.59 \%)$ of the respondents disagree, while $9(6.67 \%)$ of the respondents strongly disagree. Thus, it is important to note that most of the respondents agree to the fact that treasury single account, if put into a practice will that treasury single account compliance (TSAC) is acceptable by The Polytechnic Ibadan, enhances effective accounting practices, also there is effective and smooth running TSAC by The Polytechnic Ibadan.

The responses from second question shows that 17 (12.59\%) of the respondents strongly agree, $49(36.296 \%)$ respondents agree, $29(21.48 \%)$ of the respondents were undecided, 25 $(18.5 \%)$ of the respondents disagree, while $15(11.1 \%)$ of the respondents strongly disagree. Thus, it is important to note that most of the respondents agree to the fact that treasury single account, if put in practice will enhance the effective accounting practice and smooth running of TSAC by The Polytechnic Ibadan.

The responses from the third question shows that $26(19.26 \%)$ of the respondents strongly agree, $60(44.44 \%)$ respondents agree, $35(25.93 \%)$ were undecided, $9(6.67 \%)$ of the respondents disagree, while $5(3.70 \%)$ of the respondents strongly disagree. Thus, it is important to note that most of the respondents agree to the fact that treasury single account, if put into a practice will significantly assist in blocking revenue leakages. Therefore, this question was used in testing the first hypothesis.

The responses from question four shows that $20(14.81 \%)$ of the respondents strongly agree, $50(37.04 \%)$ respondents agree, $43(31.85 \%)$ of the respondents were undecided, 22 $(16.30 \%)$ of the respondents disagree, while $00(00 \%)$ of the respondents strongly disagree. Thus, it is important to note that most of the respondents agree to the fact that treasury single account, if put into practice will help in curbing mismanagement and misapplication of revenue.

The responses from question five shows that $31(22.96 \%)$ of the respondents strongly agree, $62(45.93 \%)$ of the respondents agree, $22(16.30 \%)$ of the respondents were undecided, $18(13.33 \%)$ of the respondents disagree, while $02(1.48 \%)$ of the respondents strongly disagree. Thus, it is important to note that most of the respondents agree to the fact that treasury single account, if put into practice will significantly reduce corruption.
The responses from question six shows that $25(18.52 \%)$ of the respondents strongly agree, $63 \quad(46.67 \%)$ of the respondents agree, $32(23.70 \%)$ of the respondents were undecided, $11(8.15 \%)$ of the respondents disagree, while $04(2.96 \%)$ of the respondents strongly disagree. Thus, it is important to note that most of the respondents agree to the fact that treasury single account, will promotes transparent reportage in a system. Therefore, this question was used in testing the second hypothesis.

The responses from question seven shows that $49(36.30 \%)$ of the respondents strongly agree, $47(34.81 \%)$ of the respondents agree, $30(22.22 \%)$ of the respondents were undecided, $07(5.19 \%)$ of the respondents disagree while 02 $(1.48 \%)$ of the respondents strongly disagree. Thus, it is important to note that most of the respondents strongly agree to the fact that treasury single account, if put into practice will significantly influence the changing in government policies.

The responses from question eight shows that $26(19.26 \%)$ of the respondents strongly agree, $49(36.30 \%)$ of the respondents agree, $42(31.11 \%)$ of the respondents were undecided, $15(11.11 \%)$ of the respondents disagree while $03(2.22 \%)$ of the respondents strongly disagree. Thus, it is important to note that most of the respondents agree to the fact that treasury single account, will lead to bureaucracy.

The responses from question nine shows that17 (12.59\%) of the respondents strongly agree, $64(47.41 \%)$ of the respondents agree, $42(31.11 \%)$ of the respondents were undecided, $12(8.89 \%)$ of the respondents disagree, while $00(00 \%)$ of the respondent strongly disagree. Thus, it is important to note that most of the respondents agree to the fact that TSAC would enhances accounting practices, if put into practice.

The responses from question ten shows that 21(15.56\%) of the respondents strongly agree, $55(40.74 \%)$ of the respondents agree, $37(27.41 \%)$ of the respondents were undecided, 19 (14.07\%) of the respondents disagree, while $03(2.22 \%)$ of the respondents strongly disagree. Thus, it is important to note that most of the respondents agree to the fact that treasury single account, if put in practice will significantly affect sustainability in institutions.

The responses from question eleven shows that 35 (25.93\%) of the respondents strongly agree, $41(30.37 \%)$ of the respondents agree, $35(25.93 \%)$ of the respondents were undecided, $22(16.30 \%)$ of the respondents disagree, while $02(1.48 \%)$ of the respondents strongly disagree. Thus, it is important to note that most of the respondents agree to the fact that treasury single account, if put in practice will significantly affect the liquidity on money deposited in Banks.

The responses from question twelve shows that $22(16.30 \%)$ of the respondents strongly agree, $56(41.48 \%)$ of the respondents agree, $43(31.85 \%)$ of the respondents were undecided, 10 (7.41\%) of the respondents disagree, while $04(2.96 \%)$ of the respondents strongly disagree. Thus, it is important to note 
that most of the respondents agree to the fact that treasury single account, if put in practice will significantly help to conserve funds for development.

$H_{1}$ : There is no significant relationship between treasury single account compliance and plug leakages within the system.

Chi-Square Test Statistics

\begin{tabular}{|c|c|c|c|c|c|}
\hline & $\begin{array}{c}\text { Observed } \\
(\mathrm{o})\end{array}$ & $\begin{array}{c}\text { Expected } \\
(\mathrm{e})\end{array}$ & $\begin{array}{c}\text { Residual } \\
(\mathrm{o}-\mathrm{e})\end{array}$ & $(\mathrm{o}-\mathrm{e})^{2}$ & $\begin{array}{c}\sum(\mathrm{o}-\mathrm{e})^{2} \\
\mathrm{E}\end{array}$ \\
\hline $\begin{array}{c}\text { Strongly } \\
\text { Agree }\end{array}$ & 26 & 27 & -1 & -1 & -0.037 \\
\hline Agree & 60 & 27 & 33 & 1089 & 40.333 \\
\hline Undecided & 35 & 27 & 8 & 64 & 2.370 \\
\hline Disagree & 09 & 27 & -18 & 324 & 12.000 \\
\hline $\begin{array}{c}\text { Strongly } \\
\text { Disagree }\end{array}$ & 05 & 27 & -22 & 484 & 17.925 \\
\hline Total & 135 & 135 & & & 72.591 \\
\hline
\end{tabular}

$\mathrm{X}^{2} \alpha, \mathrm{df}$

$\mathrm{X}^{2}{ }_{0.05,4}=9.488$

\section{Interpretation}

The table above shows that Treasury single account if put into practice will significantly assist in blocking revenue leakages as most of respondents agreed to the fact. Since the calculated $\mathrm{X}^{2}$ is greater than tabulated $\mathrm{X}^{2}$ at 0.05 level of significance, it therefore indicates that, there is a positive relationship between treasury single account and effective accounting practices by blocking the revenue leakages within the system. As a result, we therefore reject the null hypothesis of no significant relationship between treasury single account and effective accounting practices by accepting the alternative. Hence, a significant relationship exists between treasury single account and effective accounting practices.

$\mathrm{H}_{2}$ : There is no significant relationship between treasury single account compliance and dovetail into a transparent reportage within the system.

Chi-Square Test Statistics

\begin{tabular}{|c|c|c|c|c|c|}
\hline & $\begin{array}{c}\text { Observed } \\
(\mathrm{o})\end{array}$ & $\begin{array}{c}\text { Expected } \\
(\mathrm{e})\end{array}$ & $\begin{array}{c}\text { Residual } \\
(\mathrm{o}-\mathrm{e})\end{array}$ & $\begin{array}{c}(\mathrm{o}- \\
\mathrm{e})^{2}\end{array}$ & $\begin{array}{c}\sum(\mathrm{o}-\mathrm{e})^{2} \\
\mathrm{E}\end{array}$ \\
\hline $\begin{array}{c}\text { Strongly } \\
\text { Agree }\end{array}$ & 25 & 27 & -2 & -2 & -0.074 \\
\hline Agree & 63 & 27 & 36 & 1296 & 48.000 \\
\hline Undecided & 32 & 27 & 5 & 25 & 0.926 \\
\hline Disagree & 11 & 27 & -16 & 256 & 9.481 \\
\hline $\begin{array}{c}\text { Strongly } \\
\text { Disagree }\end{array}$ & 04 & 27 & 23 & 529 & 19.593 \\
\hline Total & 135 & 135 & & & 77.926 \\
\hline
\end{tabular}

$\mathrm{X}^{2} \alpha, \mathrm{df}$

$\mathrm{X}^{2}{ }_{0.05,4}=9.488$

\section{Interpretation}

The table above shows that Treasury single account if put into practice will promotes transparency and accountability as most of respondents agreed to the fact. Since the calculated $\mathrm{X}^{2}$ is greater than tabulated $X^{2}$ at 0.05 level of significance, it therefore implies that there is a positive relationship between treasury single account and effective accounting practices by promotes transparency and accountability within the system. As a result, we therefore reject the null hypothesis of no significant relationship between treasury single account and effective accounting practices by accepting the alternative. Hence, a significant relationship exists between treasury single account and effective accounting practices.

\section{IV.DISCUSSION OF FINDINGS}

More analysis of the research data produced the succeeding result findings, The Polytechnic Ibadan treasury single account compliance as effective accounting practices and sustainability in institution has increased tremendously. Major respondents approved that transparency in management of public fund were the conditions that hasty the state government to announce treasury single account compliance. Their response indicates that they are ready to conform with the treasury single account by blocking revenue leakages, curbing mismanagement and misappropriation of revenue, reduced corruption.

Accountability stresses three pre-requisite settings to function efficiently: good financial reporting, sound management system, effective sustainability in institution and good governance (Okolieaboh, 2016). Budgeting and budgetary sequence demands for actions and approaches which aid management of funds to innumerable echelons of obligation. Implications of treasury single account affects sustainability in institution.

The liquidity on money deposited in banks stands as an obstacle hindering the smooth compliance on treasury single account. Oru and Odumusor,2019; Obinna, 2015;\& Hamisu, 2015) in their studies of effect of treasury single account on liquidity of deposit money banks and effective control of governments cash resources in Nigeria. Their results discovered that the procedure operation and its model have substantial influence on the liquidity of deposit money banks and has not offered governments real regulator of its funds as accountability and transparency are not however as their peak. Defiance to changes on government policies was due to lack of awareness of benefits associated with treasury single account. Bureaucracy were also defiant because of delaying other financial claims were not promptly paid in time. Mboto, Offiong \& Ibor (2017), in their studies of public perception of the treasury single account in Nigeria. Their results disclose a noteworthy reception of the TSA policy situation nonetheless, a non-momentous constructive awareness of its process. They contends that TSA, as functioned at the moment, has depressingly pretentious the socio-economic life of the people and the process of Government Ministries, Departments and 
Agencies (MDA) as a consequence of interruptions practiced in issues owing to bureaucratic blockages. Finally, the several controls in relations to checks and balances should be created into the system.

\section{CONCLUSION}

Based on the analysis and findings of this study, it has been concluded that treasury single account compliance has significant relationship as the effective accounting practices and sustainability in institution. Thus, The Polytechnic Ibadan is complying with treasury single account which promotes transparency, accountability, helps in curbing mismanagement as well as misappropriation of revenue, reduced corruption and as well reducing bureaucracy in treasury single account compliance.

\section{RECOMMENDATIONS}

i. Government should champion the regeneration of core value of integrity, honesty, fairness, justice as a way of reforming the economy at all arms of government.

ii. Government must investigate to a logical conclusion the issue of budget padding, make the report of the investigation public and be fully implemented.

iii. The effectiveness of treasury single account compliance (TSAC) should be permissive for the sustainability in institutions. There should be seal for both transparency and accountability to plug the financial crime.

\section{REFERENCES}

[1] Abayelu, A. E. (2015). Effects of corruption and economic reforms on economic growth and development: Lessons from Nigeria, being a paper prepared and submitted For African Economic Conference.

[2] Adeolu, I. A. (2016). Understanding the treasury single account system - Things you should know. [(2010), Treasury] Business \& Economy, Market Development. Nairaland Forum / Nairaland / General / Politics. February 2016.

[3] Adeolu I. A. (2015) Business and economy; market developmentunderstanding the Treasury Single Account (TSA) system. John Archers Publishers, Nigeria

[4] Akpa, B. (1997). Accountability and transparency for economic growth and development, Discussion paper presented at ANAN National Conference, Jos, September 25.

[5] Akharayi, C. The establishment of audit committees in the public sector: A necessity for financial oversight. The official Journal of The Institute Chartered Accountants of Nigeria, 48(2), 35, April/June.

[6] Bashir, Y.M. (2016). Effects of treasury single account on public finance management in Nigeria. Journal of Finance and Accounting, 7(6), 164-170.

[7] Blackburn, K., \& Forques-Puccio, G. (2009). Why is corruption less harmful in some countries than in others? Journal of Economics Behaviour and Organization, 72, 797-810.

[8] Blackburn, K., \& Sarmah, R. (2008). Corruption development and demography. Economics and Governance, 9, 341-362.

[9] Burdhan, P. (2006). The economist's approach towards corruption. World Development, 34(2), 341-348.

[10] Central Bank of Nigeria (2015). "Revised guidelines for compliance with treasury single account by Banks in Nigeria".

[11] Cohen, S. (2016). "Accountability: A collective responsibility". Presented paper at the $46^{\text {th }}$ Annual Accountants' Conference of the institute of Chartered Accountants of Nigeria (ICAN) on Tuesday, October 11, Abuja, Nigeria.

[12] Daily Trust (2015). Academic Staff Union of Nigerian Universities on TSA Policy, Daily Trust Editorial, August. 18

[13] Dowling, J., Pfeffer, J. (1975). Organizational legitimacy: Social values and organizational behaviour. The Pacific Sociological Review, 18(1), 122-136.

[14] Ekubiat, J.U., \& Ime, E. E (2016). Adoption of Treasury Single Account (TSA) by State Governments of Nigeria: benefits, challenges, and prospects. Journal of Finance and Accounting 4: 126-130.

[15] Federal Republic of Nigeria (2010). The constitution of the Federal Republic of Nigeria 1999 (as amended). Federal Government Press, Lagos.

[16] Grubber, J. (2005). Public finance and policy. New York: Work Publications.

[17] Hamisu, M. (2015). "MDAs, banks under pressure as TSA deadline ends" Daily Trust, September 14, p.3.

[18] Harris, J. M (2000). Dimension of sustainable development Vol.1. Encyclopedia of life support systems (EOLSS) Publications.

[19] Heywood, P. (2017). Rethinking corruption: hocus-pocus, locus, and focus. Slavonic and East European Review 95(1),21-48.

[20] IMF (2010). Working paper on effective control of government single account.

[21] Independence Corrupt Practices and other related Offences Act (2000). Nigeria Law

[22] Isa, A.A. (2016). The treasury single account as an instrument of financial prudence and management: Prospects and problems. Journal of Finance and Accounting, 7(4), 66-71.

[23] Jegede, M. (2015). Buhari and the treasury single account on the liquidity. Daily Trust, September 27, 56-59.

[24] Kifasi, D. I. (2016). Fiscal responsibility in public financial management: Confronting the challenges of international public sector accounting standard. The official Journal of The Institute Chartered Accountants of Nigeria, 49(1), 5, January/March.

[25] Kirtley, O. F. (2016). Accountability and good governance: "Accountability as antidote to corruption. IFAC President presented paper at the $46^{\text {th }}$ Annual Accountants' Conference of the institute of Chartered Accountants of Nigeria (ICAN) on Tuesday, October 11, Abuja, Nigeria.

[26] Kolstad, I., Wiig, A. (2009). Is transparency the key to reducing corruption in resource-rich countries? World Development 37(3), 521-32.

[27] Kopits, G., \& Craig, J. (1998). Transparency in government operations, Occasional Paper No. 158, The Guardian, May 4.

[28] Marquette, H., Peiffer, C. (2014). Corruption and collective action: Shifting the equilibrium? Research Paper No. 32, Birmingham: Development leadership program, University of Birmingham.

[29] Mboto, H.W., Offiong, A.I., \& Ibori, B.I. (2017). Public perception of the treasury single account in Nigeria. Journal of Economics and Development Studies, 5(2), 68-77.

[30] Nelson, C., Adeoye T. \& Ogah D. (2015). Treasury single account: Giving life to Jonathan's dead policy directives. Sunday Guardian Newspaper, 2, $52-58$.

[31] Obinna, C. (2015). Banks face liquidity strain as FG fully enforces treasury single account. Thisday, Monday, 11 August, p.52.

[32] Oguntodu, J.A., Alalade, Y.S.A., Adekunle, Y.A., \& Adegbie, F.F. (2016). Treasury single account and Nigeria's economy between 1999 and 2015: An assessment. Journal of Accounting and Financial Management. 2 (6) $61-74$.

[33] Oiken, B. (2009). Corruption Perception Vs. Corruption reality. Journal of Public Economics 93(7- 8), 950-964.

[34] Okolieaboh, S. (2016). Treasury Single Account: Implementation and Challenges. This Day Live - 16 August.

[35] Onyekpere, N.N. (2015). Public Policy Effects of Treasury Single Account in Nigerian Banks. Vanguard Newspaper Editorial. August 14, p.15.

[36] Oru, A.O., \& Odumusor, C.J. (2019). Effect of treasury single account on liquidity of deposit money banks and effective control of governments cash resources in Nigeria. IOSR Journal of Economics and Finance, 10(1), 49-59. 
[37] Oyedele, T. (2015). Treasury single account and taxation. PWC Nigeria. Retrieved from http://pwcnigeriatypepad.com/files/tsa-andltax.

[38] Oyedele, T. (2016). Treasury Single Account and Taxation. Retrieved from PWC: http://www.pwc.com/nigeriataxbloog.

[39] Oyedokun, G. E. (2016). Imperative of Treasury Single Account (TSA) in Nigeria. Retrieved from https://ssrn.com/abstract $=2910315$

[40] Rijckeghem, V. C., \& Weder, B. (2007), 'Corruption and Rate of Temptation: Do Low Wages in the Civil Service Cause Corruption? IMF Working Paper 97/73, Washington, International Monetary Fund.
[41] Transparency International (2012 \& 2013). Nigerian survey and corruption survey studies June 2003. Institute of Development Studies, Ahmadu Bello University, Zaria, Kaduna.

[42] Udo, E.J. \& Esara, I.E. (2016). Adoption of treasury single account (TSA) by state government of Nigeria: Benefits, challenges, and prospects. Journal of Finance and Accounting 4 (3) 126 - 130

[43] Vishney, R., \& Schleifer A., (2003). Corruption in Quarterly Journal of Economics, Vol. 59 World Bank (2011). Curbing fraud, corruption, and collusion in the roads sector. Washington D.C.

[44] World Commission on Environment and Development (1987). Special working session vol.17, Doc.149.

[45] Yusuff, M.B. (2016). Effects of treasury single account on public financial management in Nigeria. Journal of Finance and Accounting, 7(6), 164-170. 